\title{
Development of binding based on b-n-ti-al system compounds for creating a composite instrumental material for a final raining of railway parts
}

\author{
Sherzod Fayzibaev ${ }^{*}$, Oleg Ignotenko ${ }^{2}$, and Talgat Urazbaev ${ }^{1}$ \\ ${ }^{1}$ Tashkent State Transport University, Tashkent, Uzbekistan \\ 2"High Pressure Physics and Synthesis of Super hard Materials", "Scientific and Practical Center of \\ the National Academy of Sciences of Belarus for Materials science"
}

\begin{abstract}
Studying methods for producing new composite materials based on compounds of the B-N-Al-Ti system using high pressure (up to 5 $\mathrm{GPa}$ ) and temperatures (up to $1800 \mathrm{~K}$ ), studying their physical characteristics to create tool materials based on them. Studying the prospects for the further development of research and the practical use of the results.
\end{abstract}

\section{Introduction}

The current level of technology development requires the use of new materials. To create units, mechanisms, and aggregates operating for a long time at high speeds and increased loads, it is necessary to use materials with improved characteristics (strength, hardness, wear resistance, and others). Such materials include cubic boron nitride - the second in hardness after diamond; it surpasses it in chemical, thermal, and radiation resistance. However, obtaining cubic boron nitride is associated with the use of high pressures and temperatures $\left(5-8 \mathrm{GPa}\right.$ and $\left.1500-2200{ }^{\circ} \mathrm{C}\right)$. In addition, the production of single crystals is associated with additional technological difficulties. Therefore, to simplify the manufacture of tools, the processes of sintering cubic boron nitride powders with a binder are used. Recently, the attention of researchers all over the world has been focused on the use of titanium- and aluminum-containing bonds.

The obtained fundamental knowledge will allow to develop and implement at the production site of the State Scientific and Research Center of the National Academy of Sciences of Belarus for Materials Science technologies to produce tools using the developed bundle. The manufactured products will make the products of specialized enterprises of the Republic of Belarus and the Republic of Uzbekistan more competitive. Simultaneously with this fact, the issues of import substitution and export orientation will be resolved. Established marketing will help modernize and expand the existing infrastructure and attract Belarusian and Uzbek toolmakers to subcontracts, creating jobs. All these steps will help to revive the instrumental directions of the two countries.

*Corresponding author: tytmfayzibaev@yandex.ru 


\section{Methods.}

Investigation of methods for obtaining new composite materials based on compounds of the B-N-Al-Ti system using high pressure (up to $5 \mathrm{GPa}$ ) and temperatures (up to $1800 \mathrm{~K}$ ), investigation of their physical characteristics for the creation of instrumental materials on their basis are described below.

When exposed to high pressures of $5.5 \mathrm{GPa}$ and temperatures of $1750-1800{ }^{\circ} \mathrm{C}$, monocrystalline powder superhard materials are formed with specified characteristics depending on their further use (cutting, grinding, or polishing tools).

Nano- and micro-structure of cubic boron nitride is used to create composite materials for instrumental purposes, formed under thermobaric action.

A pilot experiment for the synthesis of composite materials was carried out at pressures of $5 \mathrm{GPa}$ and temperatures up to $1500{ }^{\circ} \mathrm{C}$. The installation for the synthesis of $\mathrm{BNc}$ at high pressure and temperature includes a hydraulic press up to $137 \mathrm{~A}$, a high-pressure apparatus (AHP), a power transformer for electric heating of the reaction volume of the high-pressure chamber, and an OPTRON synthesis programmer. The synthesis was carried out in an HPD with hard-alloy matrices of the "anvil with a hole" type (Figure 1).

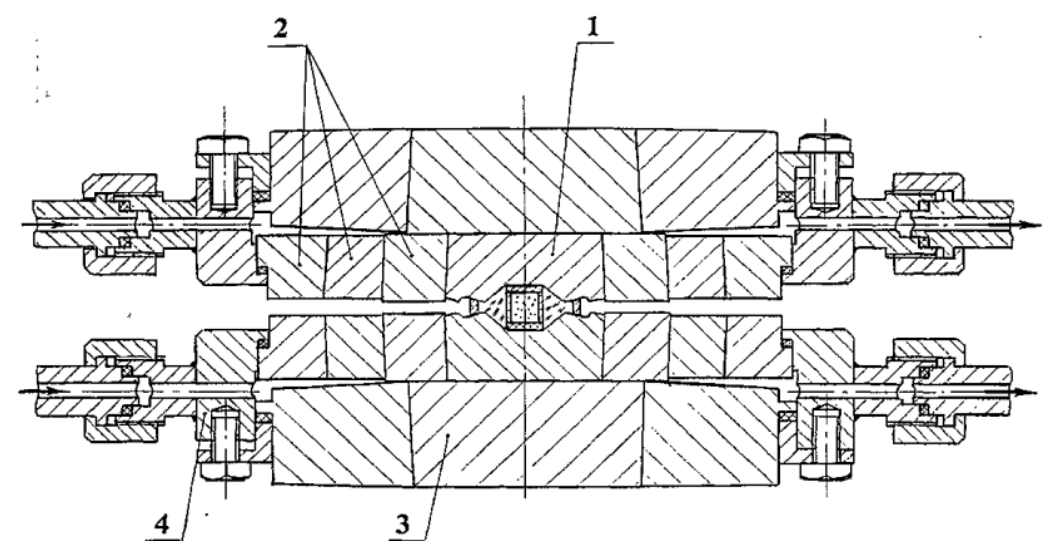

Fig. 1. High-pressure device for the synthesis of superhard materials

1 are carbide dies with a container and a heating element; 2 are steel supporting rings; 3 are carbide base plates with supporting rings; 4 is housing for water cooling (arrows indicate the direction of water inlet and outlet).

In the reaction cell of the HPA, as a rule, there is an uneven distribution of pressure over the volume. To study the real pressure distribution in the cell of an apparatus of the "anvil with a hole" type, the method of two simultaneously operating pressure sensors is successfully used. One of the sensors (zero) is installed in each experiment in a certain position, and the second (wandering) is placed at different points of the reaction volume. This allows the sensor signals to be distinguished by the magnitude of the jump in electrical resistance. According to the readings of these two sensors, the accuracy of determining the difference in pressure values is $\pm 0.01 \mathrm{GPa}$.

The pressure gradient from the zero gauge to the center of the cell in graphite reaches $0.75 \mathrm{GPa} / \mathrm{mm}$. Considering the degree of compression, the real gradient is estimated to be over $0.1 \mathrm{GPa} / \mathrm{mm}$.

The reaction mixture for synthesis, consisting of powders, was stirred for $20 \mathrm{~h}$ in a mixer with an offset axis. Then, under a pressure of $0.25 \mathrm{GPa}$, cylindrical tablets with a diameter of 10 and a height of $2 \mathrm{~mm}$ were pressed from the mixture in a steel mold at room 
temperature and placed in a composite heater pressed from a charge consisting of graphite and $\mathrm{BNg}$, located in a high-pressure chamber, after what the synthesis was carried out.

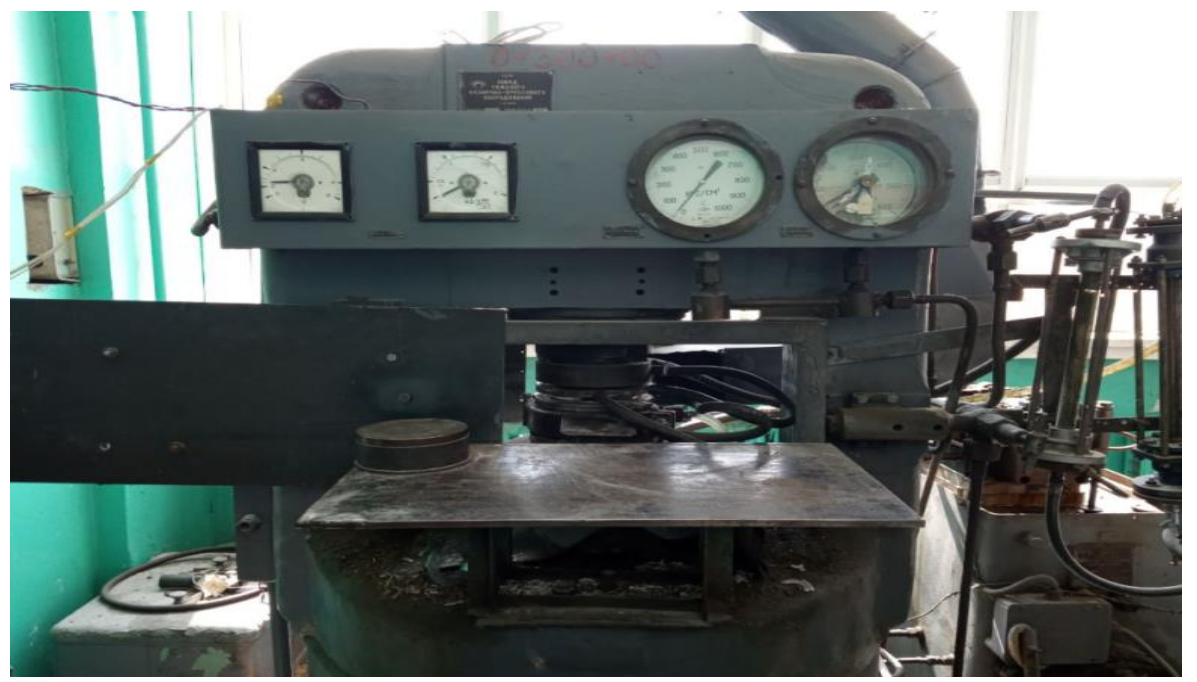

Fig. 2. High-pressure apparatus DO 137A.

The synthesis was carried out at a pressure of $5 \mathrm{GPa}$ (taking into account the thermal pressure increase equal to $\sim 0.8 \mathrm{GPa}$ ) and temperatures of $1670-1910 \mathrm{~K}$ in high-pressure carbide chambers of the "anvil with a hole" type in containers made of lithographic stone. With the given synthesis parameters, 5 identical experiments were carried out.

Phase formation studies were carried out using DRON-3 and DRON-3 M diffractometers in $\mathrm{Cr}-\mathrm{K} \alpha-$ and $\mathrm{Cu}-\mathrm{K} \alpha$-radiation at room temperature. A graphite monochromator was used to cut off the $\mathrm{K} \beta$ radiation components. The scanning step was no more than 0.03 degrees; the exposure time was no less than 5 seconds. The data was recorded automatically. The crystal structure studies were carried out by the Rietveld fullprofile analysis of X-ray structural data. The spectra were refined using the FullProf software package.

The samples of the Al-Ti system were obtained from the elementary components $\mathrm{Al}$ and $\mathrm{Ti}$ (ratio $50: 50 \%$ by mass) at a pressure of $5 \mathrm{GPa}$ (taking into account the thermal pressure increase equal to $\sim 0.8 \mathrm{GPa}$ ) and at a temperature of $1500^{\circ} \mathrm{C}$ in high-temperature carbide chambers. Pressure type "anvil with a hole" in containers made of lithographic stone. The selected synthesis conditions make it possible to obtain solid solutions of the specified system with a high degree of phase purity. 


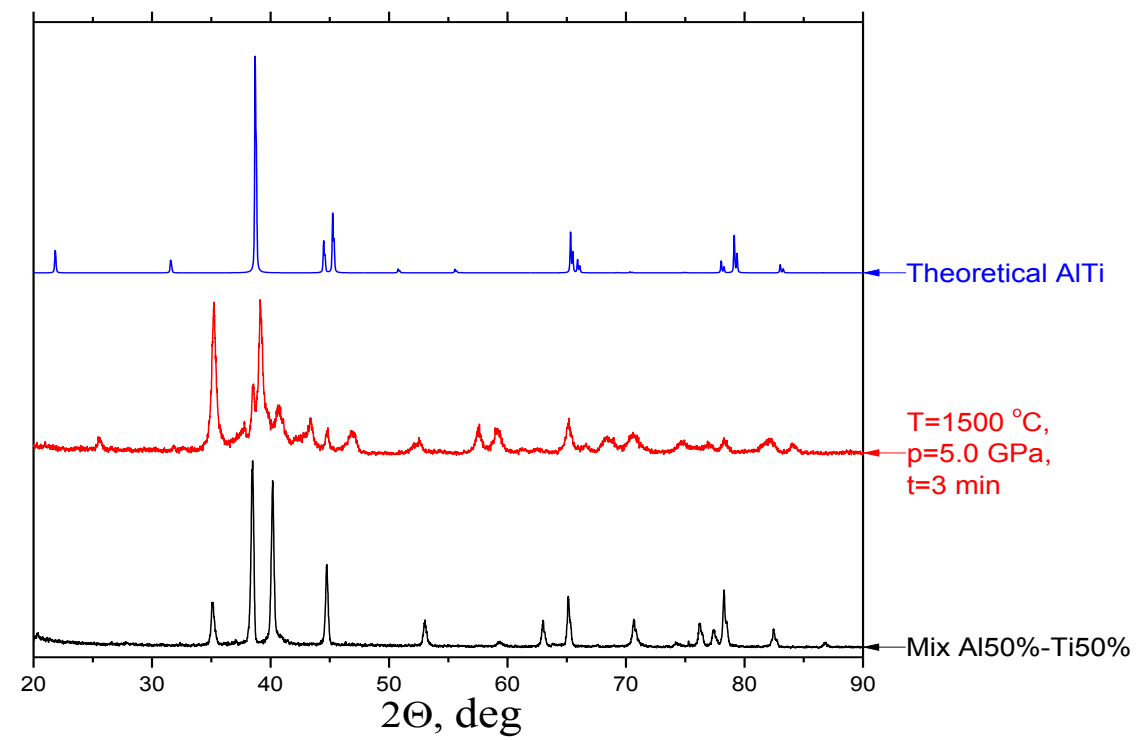

Fig. 3. X-ray diffraction spectra of Al-Ti system compounds obtained at a high pressure of 5.0 GPa from elementary components at a temperature of $1400{ }^{\circ} \mathrm{C}$

The X-ray diffraction data obtained immediately after the synthesis of compounds of the Al-Ti system at a high pressure of $5.0 \mathrm{GPa}$ and at a temperature of $1400^{\circ} \mathrm{C}$ indicate the presence of the AlTi phase. AlTi - has a tetragonal structure with crystal lattice parameters $\mathrm{a}=4.0050 \AA, \mathrm{c}=4.0700 \AA, \mathrm{a} / \mathrm{b}=1.0000 \mathrm{~b} / \mathrm{c}=0.9840 \mathrm{c} / \mathrm{a}=1.0162$. The diffractograms were refined in a single-phase model using the space group P4 / mmm (123).

Samples of the Al-BN system were obtained from elemental $\mathrm{Al}$ and the hexagonal modification of the $\mathrm{BN}$ compound (in the ratio $\mathrm{Al}: \mathrm{BN}=0.1: 1$ and $\mathrm{Al}: \mathrm{BN}=0.2: 1$ by mass) under a high pressure equal to $5.0 \mathrm{GPa}$ and at a temperature of $2500{ }^{\circ} \mathrm{C}$ with a duration synthesis 3 minutes in high-pressure carbide chambers of the "anvil with a hole" type in containers made of lithographic stone. The duration of the synthesis was established experimentally. The selected synthesis conditions make it possible to obtain compounds of the specified system with a high degree of phase purity.

The X-ray diffraction data (Figure 4-5) of the obtained samples of the Al-BN system indicate that the AlN phase is formed in the samples when exposed to high pressure of 5.0 $\mathrm{GPa}$ and at a temperature of $2500^{\circ} \mathrm{C}$. Along with the AlN phase, the samples contain other binary $\left(\mathrm{Al}_{\mathrm{x}} \mathrm{B}_{\mathrm{y}}\right)$ compounds of the $\mathrm{Al}-\mathrm{BN}$ system. This is due to the non-stoichiometric ratio of the initial charge. The obtained compound AIN (Aluminum Nitride) - has a hexagonal structure with crystal lattice parameters $\mathrm{a}=3.1130 \AA, \mathrm{c}=4.9810 \AA$. The diffractograms were refined in a single-phase model using the space group P $63 \mathrm{~m} \mathrm{c}$ (186). 


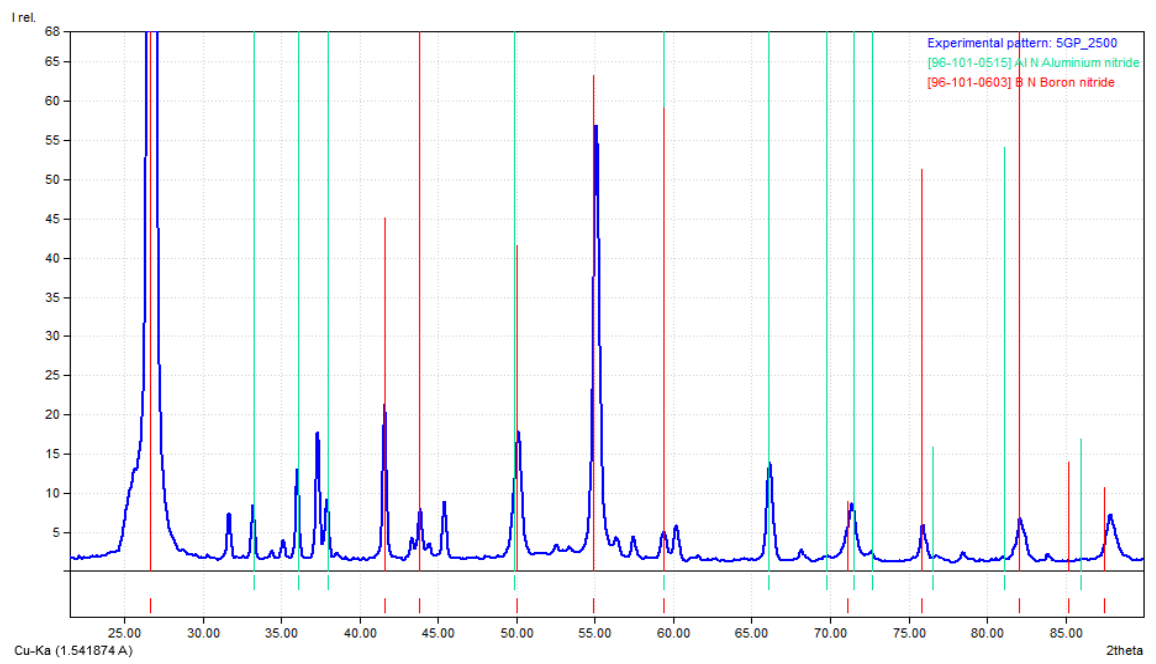

Fig. 4. X-ray phase analysis of the X-ray diffraction spectra of the obtained samples of the Al-BN system in the stoichiometric ratio $\mathrm{Al}: \mathrm{BN}=0.1: 1$ under high pressure of $5.0 \mathrm{GPa}$ at a temperature of $2500{ }^{\circ} \mathrm{C}$ with a synthesis duration of 3 minutes

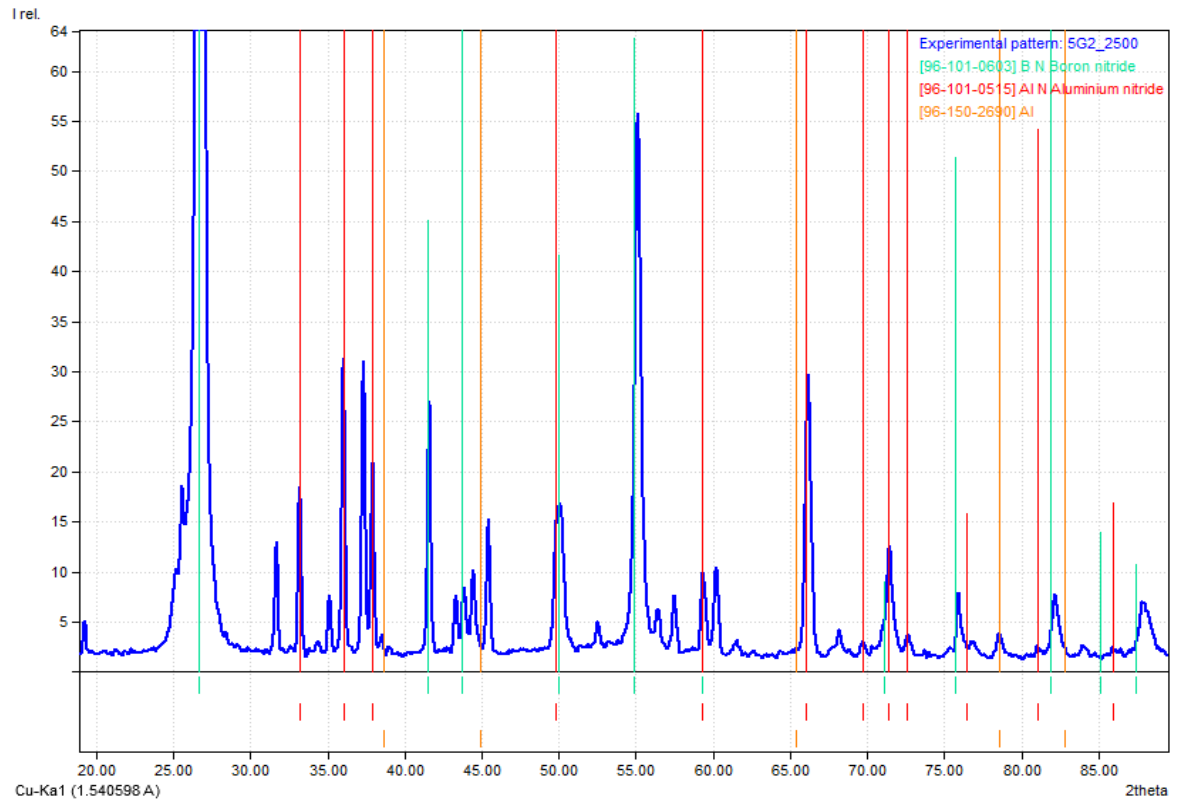

Fig.5. X-ray phase analysis of the X-ray diffraction spectra of the obtained samples of the Al-BN system in the stoichiometric experiment $\mathrm{Al}: \mathrm{BN}=0.2: 1$ under high pressure of $5.0 \mathrm{GPa}$ at a temperature of $2500^{\circ} \mathrm{C}$ with a synthesis duration of 3 minutes

Figure 6 shows the effect of the concentration of the initial elements (namely, aluminum) in the charge on the course of chemical reactions in the sample and the reactions' final products. 


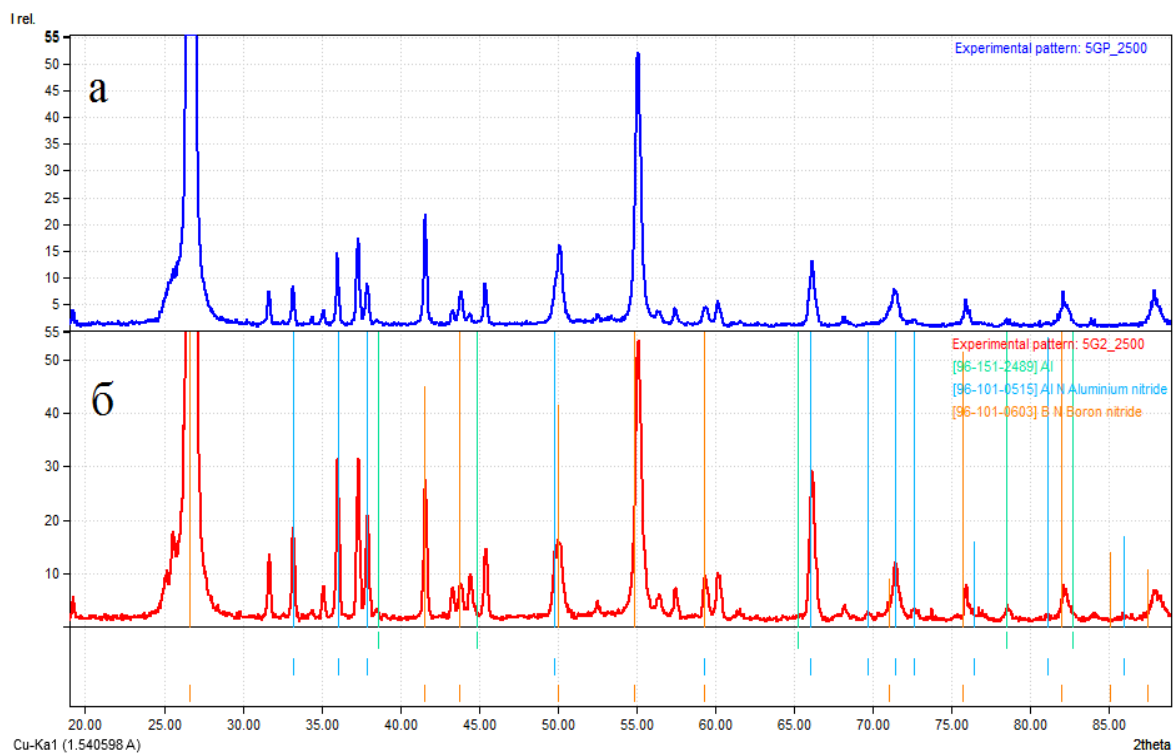

Fig. 6. X-ray phase analysis of the X-ray diffraction spectra of the obtained samples of the Al-BN system under high pressure of $5.0 \mathrm{GPa}$ at a temperature of $2500{ }^{\circ} \mathrm{C}$ with a synthesis duration of 3 minutes

(a - stoichiometric ratio $\mathrm{Al}: \mathrm{BN}=0.1: 1 ; \mathrm{b}$ - stoichiometric ratio $\mathrm{Al}: \mathrm{BN}=0.2: 1$ )

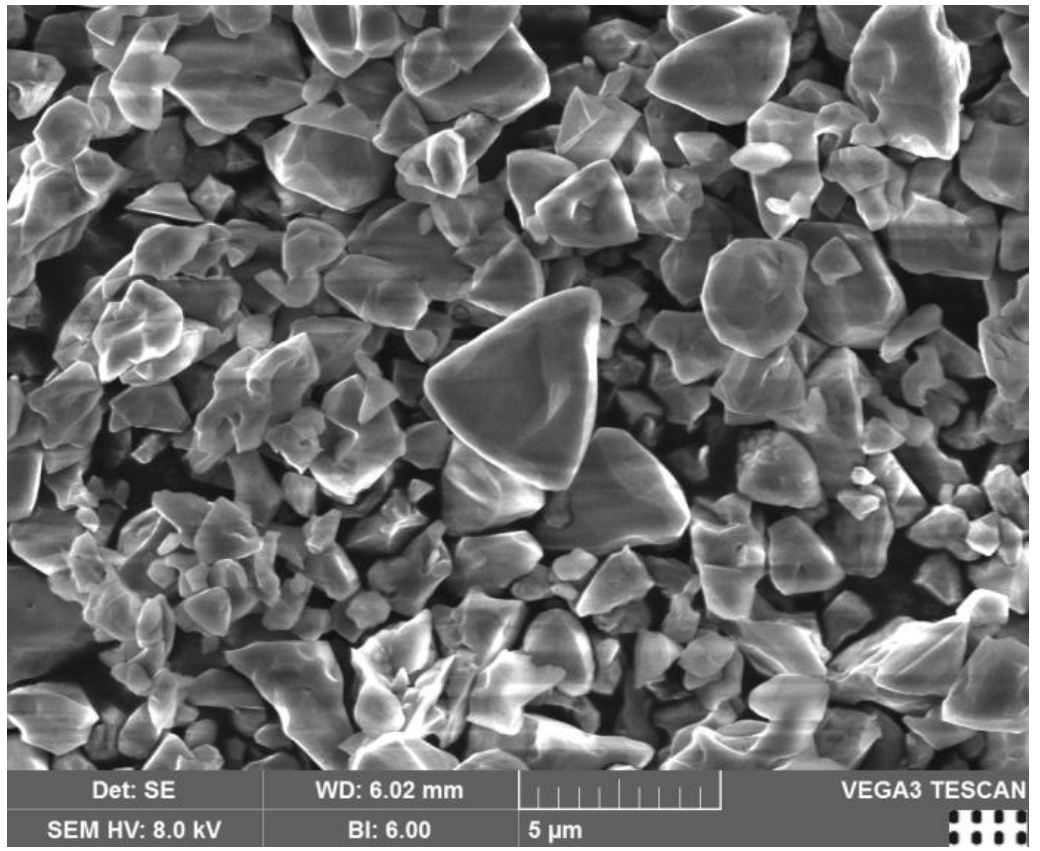

Fig. 7. microstructure of cBN samples, sintered at a pressure of $8 \mathrm{GPa}$ 
Table 1. Mechanical properties of composite materials based on cubic boron nitride.

\begin{tabular}{|c|c|c|c|}
\hline № & Name & \multicolumn{2}{|c|}{ Value } \\
\hline 1 & Hardness & $30-45$ & $\mathrm{GPa}$ \\
\hline 2 & Crack resistance & $12-16$ & $\mathrm{MPa} \bullet \mathrm{m}^{1 / 2}$ \\
\hline 3 & $\begin{array}{c}\text { Resistance when turning hardened } \\
\text { steels (HRC 52-54) }\end{array}$ & 60 & $\mathrm{~min}$. \\
\hline 4 & Grain size & $5-30$ & $\mathrm{mcm}$ \\
\hline 5 & Depth of cut up to & 0,5 & $\mathrm{~mm}$ \\
\hline 6 & Feed & $0,05-0,15$ & $\mathrm{~mm} / \mathrm{tur}$. \\
\hline 7 & Cutting speed & $200-125$ & $\mathrm{~m} / \mathrm{min}$. \\
\hline
\end{tabular}

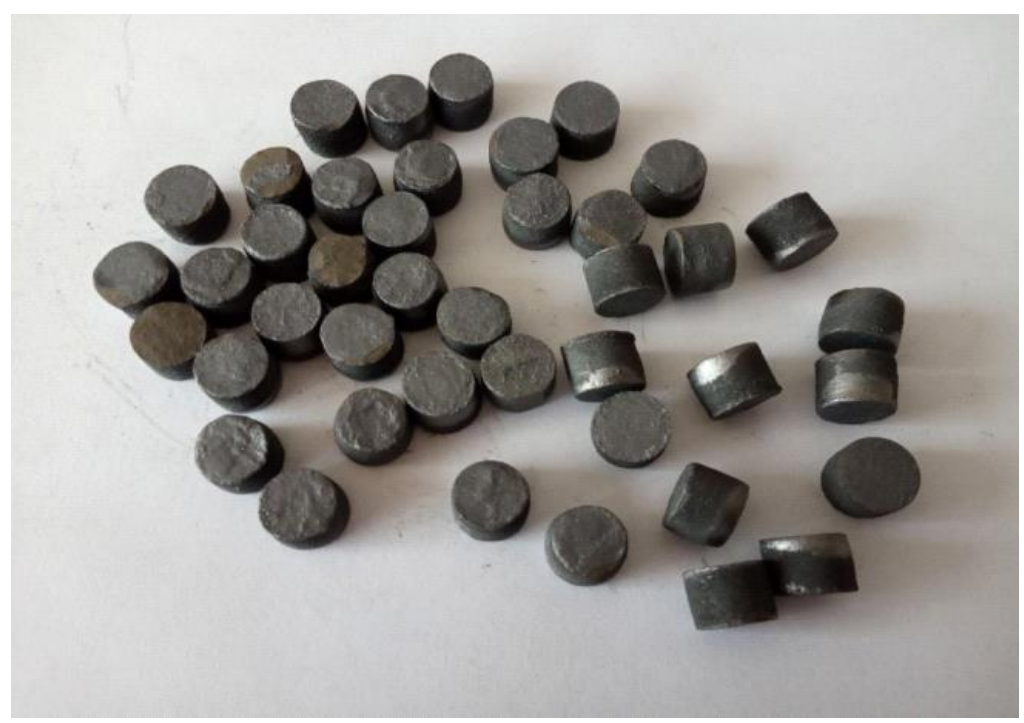

Fig. 8. Obtained high-pressure synthesis samples (without machining)

Experimental studies of the cutting properties of cutters based on B-N-Al-Ti system joints were carried out at the Tashkent Diesel Locomotive Repair Plant and the Tashkent Foundry and Mechanical Plant. The studies were carried out by changing the cutting tool operating mode parameters during the finishing of parts.

At the "Tashkent Diesel Locomotive Repair Plant", the shaft $\varnothing 57 \mathrm{~mm}$ of a blower made of steel grade $12 \mathrm{XN} 3 \mathrm{~A}$ with a hardness of $56 \mathrm{HRC}$, with the parameters of the cutter operating mode: cutting feed $0.05 \mathrm{~mm} / \mathrm{rev}$, cutting depth $0.1 \mathrm{~mm}$, cutting speed $285 \mathrm{~m} /$ min. The working time of the cutter was 88 minutes (Figure 9). 


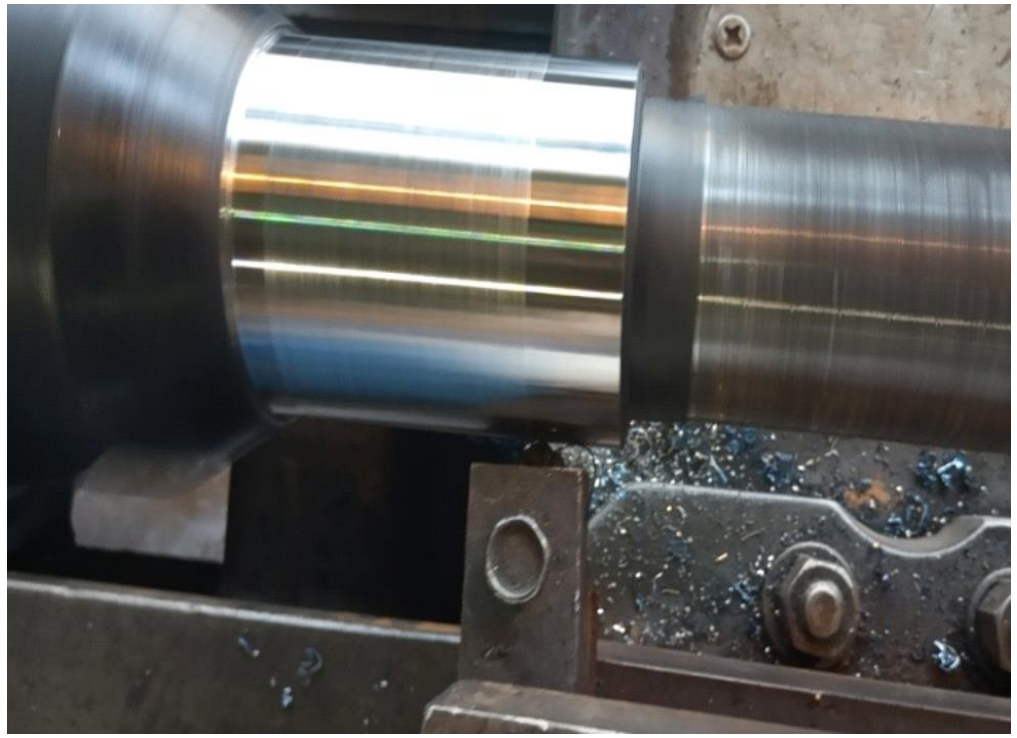

Fig. 9. Turning a shaft $\varnothing 57 \mathrm{~mm}$ from steel grade $12 \mathrm{XN} 3 \mathrm{~A}$ with a cutter feed of $0.05 \mathrm{~mm} / \mathrm{rev}$ and a cutting speed of $285 \mathrm{~m} / \mathrm{min}$.

External longitudinal turning of a shaft $\varnothing 57 \mathrm{~mm}$ was carried out with the following mode parameters: tool feed $0.15 \mathrm{~mm} / \mathrm{rev}$, cutting depth $0.1 \mathrm{~mm}$, cutting speed $229.1 \mathrm{~m} / \mathrm{min}$. The working time of the cutter was 82 minutes (Figure 10).

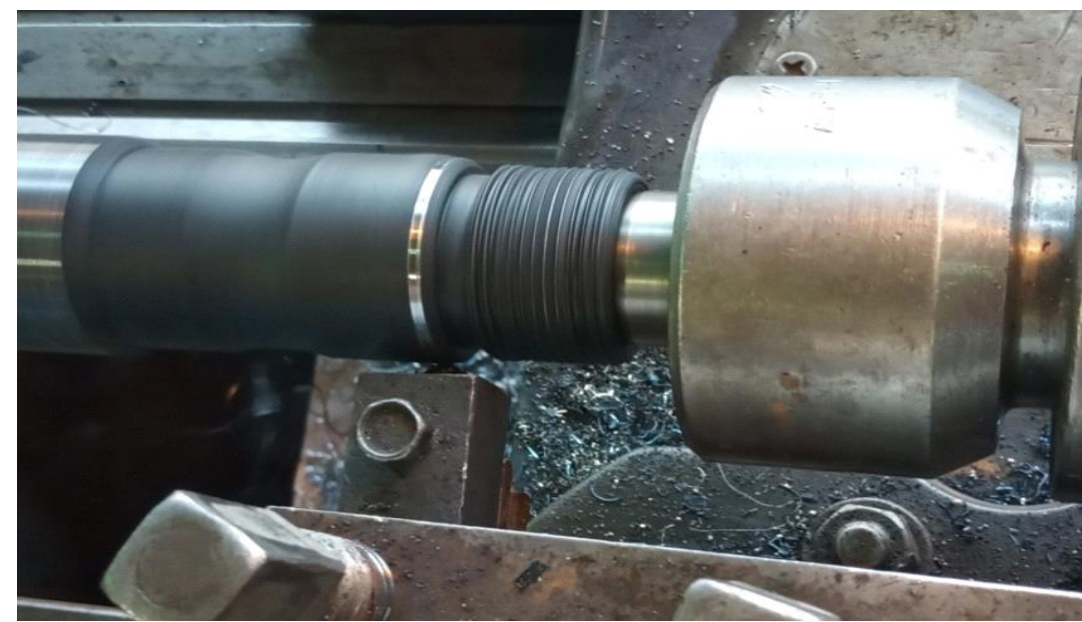

Fig. 10. External longitudinal turning of a shaft $\varnothing 57 \mathrm{~mm}$ from steel grade $12 \mathrm{XN} 3 \mathrm{~A}$ cutter feed 0.15 $\mathrm{mm} / \mathrm{rev}$ and cutting speed $229.1 \mathrm{~m} / \mathrm{min}$.

Also, impact tests were carried out on a shaft $\varnothing 60 \mathrm{~mm}$ of a blower with a length of the grinded surface of $70 \mathrm{~mm}$ made of steel grade 12XH3A, with a hardness of $56 \mathrm{HRC}$. Shaft turning mode parameters: cutter feed $0.05-0.1-0.15 \mathrm{~mm} / \mathrm{rev}$, cutting depth up to 0.5 $\mathrm{mm}$, cutting speed $125-200 \mathrm{~m} / \mathrm{min}$. The working time of the cutter until complete wear was 15-30 minutes (Figure 11). According to the tests' results on the processing of toothed surfaces, the following turning mode is recommended: cutting feed $0.05 \mathrm{~mm} / \mathrm{rev}$, cutting depth up to $0.1 \mathrm{~mm}$, cutting speed $125 \mathrm{~m} / \mathrm{min}$. 


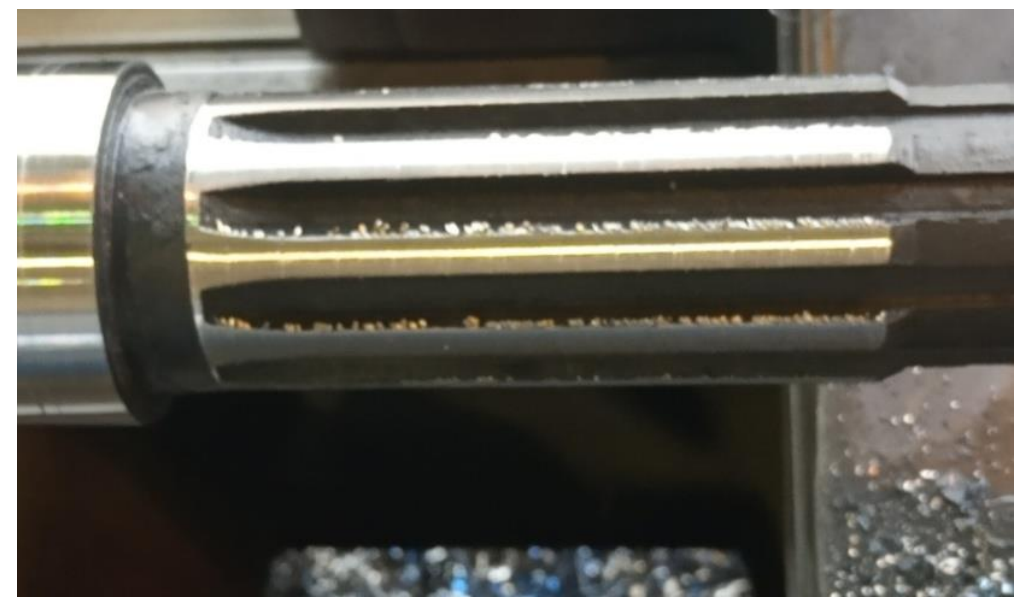

Fig. 11. Machining by impact on the shaft $\varnothing 60$ with the length of the turned toothed surface $70 \mathrm{~mm}$ made of steel grade $12 \mathrm{XN} 3 \mathrm{~A}$

At the DP "Tashkent Foundry and Mechanical Plant" when turning parts made of steel grade $5 \mathrm{XNM}$ with hardness $>52 \mathrm{HRC}$ with the parameters of the cutter operating mode: cutter feed $0.05-0.1-0.15 \mathrm{~mm} / \mathrm{rev}$, cutting depth up to $0.5 \mathrm{~mm}$, cutting speed 242.1 $210.7-194.3 \mathrm{~m} / \mathrm{min}$.

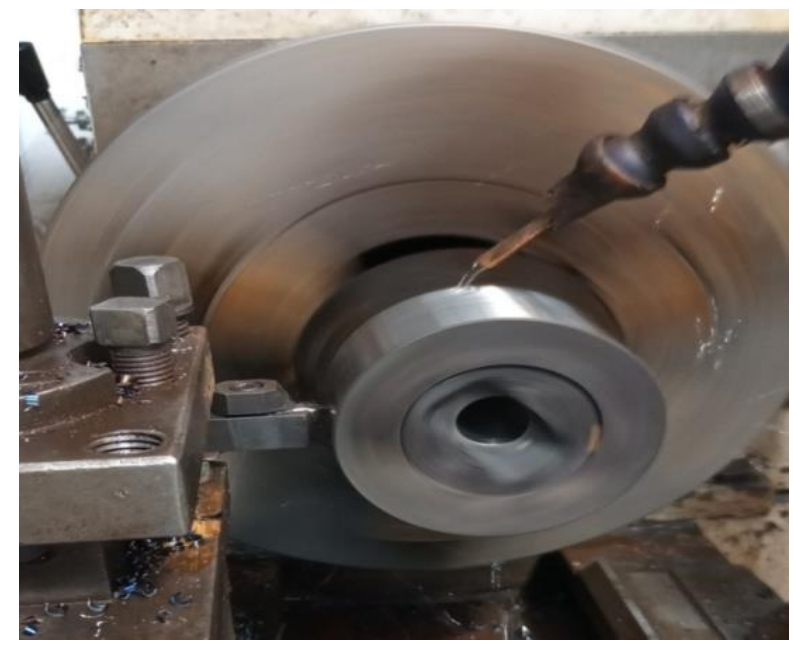

Fig. 12. Shaft turning $\varnothing 100 \mathrm{~mm}$ from steel grade $5 \mathrm{XNM}$

The experiments carried out showed that, subject to the cutting conditions, the working time of the cutters was 78 - 88 minutes (Figure 12).

\section{Conclusions}

The obtained composite compounds are a prerequisite for creating a binder based on the TiAl system for specific industry tasks.

Based on several connections of the system, changing the composition, and not significantly adjusting the technological process, it is possible to quickly obtain instrumental composite materials of various directions. 
Several mechanical tests have been carried out on various grades of steel. At the same time, the working time of the cutters (durability) was 78 - 88 minutes.

Experimental studies of cutting properties of cutters based on B-N-Al-Ti system joints have been carried out. Recommendations on rational conditions and modes of cutting tools using superhard composite tool materials have been developed.

\section{References}

1. Eilon Faran, Irena Gotman, Elazar Y. Gutmanas, Experimental study of the reaction zone at boron nitride ceramic-Ti metal interface, Materials Science and Engineering A288. pp.66-74, (2000)

2. Ewa Benkoa, Andrzej Wyczesany, Tery L. Barrc CBN-metal, metal nitride composites Ceramics International 26. pp. 639-644. (2000).

3. E. Benko, T.L. Barr, S. Hardcastle, E. Hoppe, A. Bernasik, J. Morgiel XPS study of the cBN-TiC system Ceramics International27. pp. 637-643. (2001)

4. J. Morgiel, E. Benko Microstructure of boron nitride sintered with titanium Materials Letters 25. pp.49-52, (1995)

5. E. Benko $\mathrm{CBN}-\mathrm{TiH}_{2}$ composites: chemical equilibria, microstructure and mechanical studies Diamond and Related Materials 6. pp.1192-1197, (1997)

6. Faizibaev Sh.S., Soboleva I.Yu., Zainidinov O.I., Urazbaev T.T., Samborskaya N.A., On the formation of composite compounds of the (Ti-Al) system, Fundamental and Applied Scientific Research, Collection of articles based on the materials of the international scientific and practical conference" Izd. SIC. VN, Part-2, April 27. - Ufa, (2019)

7. Fayzibaev Sh.S., Soboleva I.Yu., Zainidinov O.I., Urazbaev T.T., Samborskaya N.A., To the question of the formation of composite compounds of the system (Ti-Al), Slovak international scientific journal "VOL. 1. No. 29. International Center in Paris ISSN 5782-5319. (2019)

8. Faizibaev Sh.S., Ignotenko O.V., Samborskaya N.A., Urazbaev T.T., Nafasov Zh.Kh. Development of a bond based on B-N-Ti-Al system connections for creating a composite instrumental material for finishing railway parts, Republican scientific and technical conference with the participation of foreign scientists "Resource-saving technologies in railway transport", TashIIT. -Tashkent, December 20-21, (2019)

9. Libenson, G.A. Powder metallurgy processes, Formation and sintering. Moscow: MISIS, (2002)

10. Pankin N.A. Investigation of the structure of (Ti-Al) composites obtained by cold pressing of powders and solid-phase sintering, Refractory, ceramic and composite materials. Saransk: MGU, (2015).

11. Pankin N.A. (Ti-Al) composites obtained by pressing followed by sintering in air. Structure and properties, News of higher educational institutions. Volga region. Physics and mathematics. Samara, (2015)

12. Abrasive and diamond processing of materials. Directory, Mechanical Engineering. Moscow, (1977) 